\title{
Repeated flood disturbance enhances rotifer dominance and diversity in a zooplankton community of a small dammed mountain pond
}

\author{
Carmen GABALDÓN, ${ }^{1}$ Miloslav DEVETTER,,${ }^{2}$ Josef HEJZLAR,,${ }^{1}$ Karel ŠIMEK, ${ }^{1}$ Petr ZNACHOR, ${ }^{1}$ Jiří NEDOMA, ${ }^{1}$ \\ Jaromir SEDA ${ }^{1 *}$
}

${ }^{1}$ Institute of Hydrobiology, Biology Centre of Academy of Sciences of the Czech Republic, České Budějovice; ${ }^{2}$ Institute of Soil Biology, Biology Centre of Academy of Sciences of the Czech Republic, České Budějovice, Czech Republic

*Corresponding author: seda@hbu.cas.cz

\begin{abstract}
The zooplankton community in a relatively small and mountain pond was studied during the spring growing season. To investigate which factors operate in the community structure, we explored several physical conditions, such as high inflows, and the biotic dynamics of the main zooplankton groups (i.e., rotifers, cladocerans and copepods). Two extreme flood events occurred during the investigated period and caused dramatic changes in physical conditions and reduction of the planktonic community abundances. The short period between both high-flow events was enough for the recovery of microplankton, but not for the metazoan zooplankton. Our results are in agreement with the common situation in which high flood events commonly favour rotifers over crustaceans, likely due to rotifer species have great colonization ability and grow faster. However, we found that the dominance of rotifers over crustaceans in our system is evidenced by an extremely, unusual high ratio between their abundances. We observed that, at the time of the great floods, crustacean abundances as well as rotifer populations notably decreased until near zero values. Although rotifer abundance began declining before high floods, the decrease was particularly notable when the great flood happened. Our results evidenced that i) dilution rate and temperature were the main drivers which are operating in the structure of the zooplankton community; and ii) no negative biotic interactions were detected between large and small cladocerans and rotifers. Additionally, we found surprisingly that a repeated disturbance caused by high flood events does increase the species diversity of rotifers. Finally, our study also detected some cues which may indicate that diapausing egg bank is also playing an important role in the zooplankton community, favouring the dominance of rotifers; however, this phenomenon deserves further studies.
\end{abstract}

Key words: Flood events; repeated disturbance; dammed humic pond; growth rate; diapause; biotic interactions.

Received: June 2016. Accepted: December 2016.

\section{INTRODUCTION}

Zooplankton community structure and species' seasonal fluctuations are shaped by the effect of both abiotic and biotic factors (Arnott and Vanni, 1993; Ramdani et al., 2009; Chou et al., 2012). Factors such as food availability, trophic interactions, and physical conditions have an effect on the natality and mortality rates of zooplankton species whose balance translates into the intrinsic population growth rate. A direct indicator of the population birth rate in zooplankton is the amount of eggs produced (Paloheimo, 1974). Eggs recruitment has been shown to be affected by both the availability of resources (quantity and quality) and temperature (Hirche et al., 1997; Giebelhausen and Lampert, 2001). On the one hand, low food level and quality may limit the investment in egg production when maintenance of basic metabolism is needed (Ban, 1994; Kilham et al., 1997; Devetter and Seda, 2003; Niehoff, 2004). The availability of food rarely stays constant in natural systems since it depends on external environmental conditions such as nutrients, light, and temperature as well as on the presence of competitors. On the other hand, temperature slows down or speeds up metabolism processes and hence drives the rate of embryonic development (George and Hewitt, 1990; Gillooly, 2000). Regarding mortality, zooplankton population losses, expressed as death rate, result from various factors such as natural mortality (i.e., senescence), losses to predation or diseases, or losses by water washout caused by flow events. In the waterbodies where zooplanktivorous fish are present, the largest species are more vulnerable to predation by fish than the smaller ones (Brooks and Dodson, 1965; Checkly, 1982) and, hence, senescent mortality is expected to be less frequent and likely. This is so because vertebrate predators detect their prey visually and consequently they often select the larger organisms. In contrast, invertebrate predators, such as copepods, select smaller prey since they are easier to handle (Kerfoot, 1977; Moore et al., 1999; Bundy and Vanderploeg, 2002).

Zooplankton community is defined as the community of free-floating organisms which, compared to nekton (i.e., actively swimming organisms), cannot withstand 
strong water flows. Thus, in lakes with short retention times and reservoirs, the flushing rate operates as a major factor determining the zooplankton community structure (Threlkeld, 1982; Bledzki and Ellison, 2000; Mac Donagh et al., 2009). The water renewal of natural lakes depends on weather conditions (e.g., precipitations) while in a man-made reservoir the water retention time is commonly controlled by human reservoir management (Wetzel, 1990). An increased flow rate is often associated with changes in physical and chemical conditions of the environment, and may directly result in a washout of part, or even the total zooplankton population, depending on its intensity in relation to the size of the water body. It is expected that the smaller the lake or reservoir and the greater and more frequent the oscillations in flushing rates, the more severe is the impact on the zooplankton community (Threlkeld, 1982). After a high inflow event, organisms which have been able to remain in the aquatic system will begin to re-colonise the water column. Under this scenario, species which reproduce rapidly, being able to compensate their dilution, are expected to dominate in the community (Dickman, 1969). However, flood events may not have only negative influence on zooplankton community and several positive effects may be observed. For example, when part of the population is diluted as consequence of water renewal, inter- and intraspecific biotic interaction effects are likely reduced. In fact, the strength of the biotic interactions in plankton communities is proved to be lowered during hydrologically perturbed periods (Angeler et al., 2000; Quintana Pou et al., 2006) and as a consequence, competitive exclusion may be avoided, being a positive effect on the entire community. Moreover, in shallow aquatic ecosystems, high inflows are able to promote turbulences in the sediment redistributing the first layers. This likely favours the releasing of resting egg located in deep layers and, hence, it allows the access of the hatching cues (e.g., light) (Vaníčková et al., 2011). Consequently, the population re-establishment in the water column from hatchlings of diapausing eggs is promoted by inflows. Nevertheless, despite inflow rate being a factor that may cause an important alteration in the zooplankton community, its effects and the degree of its influence on lakes and reservoirs have received scarce attention in the ecological studies of zooplankton communities (Geraldes and Boavida, 2005).

Not only a strong colonizing ability but also the capability to invest in diapausing eggs are common traits of zooplankton species which live in fluctuating environments (Hairston et al., 1995; Gilbert and Schröder, 2004; Alekseev et al., 2007). Diapause operates as a strategy to overcome unsuitable conditions (Pourriot and Snell, 1983; Slusarczyk, 1995; Cáceres, 1997; Alekseev and Lampert, 2001; Brendonck and De Meester, 2003). The diapausing eggs produced drop to the bottom of the aquatic system where they are able to stay viable during long periods of time (Marcus et al., 1994; Hairston et al., 1995; Cáceres, 1998; García-Roger et al., 2006). When suitable conditions return, hatchlings from these diapausing eggs will also allow the re-colonization of the water column. As explained above, that is important under a scenario in which the zooplankton population is reduced by a high water renewal event.

The three major groups of freshwater zooplankton communities are copepods, cladocerans, and rotifers. All of them invest in diapause (Hairston, 1996) and represent a wide variety of life-history patterns (Allan, 1976). Rotifers have the smallest body sizes and, since they have relatively short embryonic development, they reproduce faster than cladocerans and copepods. This allows rotifers to be highly opportunistic and have better colonizing abilities. However, their small body size makes them more vulnerable to invertebrate predation. Cladocerans are larger than rotifers and, although they have larger clutches, their development is slower. Moreover, cladocerans have lower growth rates and less colonizing ability than rotifers. Copepods have larger body sizes and longer generation times so they reproduce more slowly than cladocerans and rotifers. Their longer generation times are due to their obligatory sexual reproduction while monogonont rotifers and cladocerans reproduce by cyclical parthenogenesis (i.e., they reproduce parthenogenetically (asexually) and also by sexual reproduction) (De Meester et al., 2004). Their larger body sizes make cladocerans and copepods more susceptible to vertebrate predation. According to these differences in life-history traits, it is expected that there will be an assemblage dominated by rotifer species after a high flow episode, especially when fish predation is present (Jenkins and Buikema, 1998).

The aim of the present study was to examine the zooplankton community structure and population fluctuation in a relatively small, artificial mountain pond, Jiřická Pond, which has an inflowing and outflowing stream via which is subjected to flood events. It contains humic water, and a relatively strong population of minnows (Phoxinus phoxinus) is present. We analysed a spring period of the zooplankton community which was disturbed by two huge flood events, shortening the typical water retention time of seven days to several hours. Due to the Jiřická Pond morphology, i.e., elongated, small, and shallow, the system is likely being mixed when high inflow happens and most zooplankton individuals are expected to be washout. However, it is also expected the recovery of zooplankton species since individuals present in deepest and sinuous parts of the ponds during the high inflow events likely suffer less the washout effect. Special attention was paid to cladoceran and rotifer species composition and diversity during the studied period. 


\section{METHODS}

The study was carried out in the montane humic Jiřická Pond (also known as Pohořský Pond), located in Novohradské Mountains in the Czech Republic

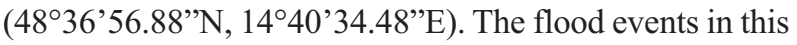
system depend on the high precipitation on the mountains. The basic limnological characteristics of the pond are presented in Tab. 1. A map representation of the Jiřická Pond is in Fig. 1.

A total of eight limnological variables were monitored at a sampling site situated close to the point of maximum depth. i) Water temperature $\left({ }^{\circ} \mathrm{C}\right)$ was measured at the depth of $0.5 \mathrm{~m}$ with a temperature logger (TidbiT v2 Water Temperature Data Logger - UTBI-001; Onset Computer Corporation, USA) at 1-hour intervals and averaged for daily values. ii) Dilution rate of the pond was calculated as a percentage of pond volume replaced by daily inflow. For that, discharge was measured with a flow meter (Flowtracker, Sontec, USA) and a stream gauge at the major tributary in to the pond (ca $0.5 \mathrm{~km}$ upstream from the pond; catchment area $11.7 \mathrm{~km}^{2}$ ) every 2-3 days from April 1 to June 30 . Water chemistry was analysed in samples from a depth of $0.5 \mathrm{~m}$. iii) Chlorophyll $a(\mathrm{Chl} a, \mu \mathrm{g} \mathrm{L}-1)$ was measured daily spectrophotometrically after extraction in $90 \%$ acetone following Lorenzen acidification protocol (Lorenzen, 1967). Moreover, every 1-3 days from May 5 to June 27, 2014, iv) dissolved organic carbon (DOC, $\mathrm{mg} \mathrm{L}^{-1}$ ) (in samples filtered through glass-fiber filters of $0.4 \mu \mathrm{m}$ pore size (GF-5, Macherey-Nagel) with a TOC5000A analyser, Shimadzu), and v) particulate organic carbon (POC, $\mathrm{mg} \mathrm{L}^{-1}$ ) (on GF-5 filters by high-temperature ignition with a SSMTOC5000A analyser, Shimadzu) were determined. Additionally, DOC and POC were measured on April 22, 2014. vi) Bacterial and protozoan abundances and sizes were determined every 2-3 days (three times a week) from May 5 to June 27,2014 . For bacterial enumeration and sizing, duplicate formaldehyde-fixed subsamples of 1-2 $\mathrm{mL}$ were filtered onto black $0.2 \mu \mathrm{m}$ pore-size membrane filters, stained with the DAPI fluorochrome and the bacterial abundance was determined via epifluorescence microscopy as described Simek et al. (2008). Bacteria (> 300 cells per sample) were sized by using the semiautomatic image analysis systems (NIS-Elements 3.0, Laboratory Imaging, and Prague, Czech Republic). For vii) heterotrophic flagellates (HNF, $\mu \mathrm{m}^{3} \mathrm{~mL}^{-1}$ ) and viii) ciliates $\left(\mu \mathrm{m}^{3} \mathrm{~mL}^{-1}\right)$, duplicate formaldehyde-fixed subsamples of 5-10 $\mathrm{mL}$ and $10-30 \mathrm{~mL}$, respectively, were filtered onto black $1 \mu \mathrm{m}$ pore-size membrane filters and stained with the DAPI. Then, the protozoan abundances (i.e., HNF and ciliates) were determined via epifluorescence microscopy as detailed in Šimek et al., (Šimek et al., 2014). To calculate mean volumes of HNF and ciliate cells (approximated to prolate spheroids), lengths and widths of 50 cells were measured manually onscreen with a built-in tool of a PC-based image analysis

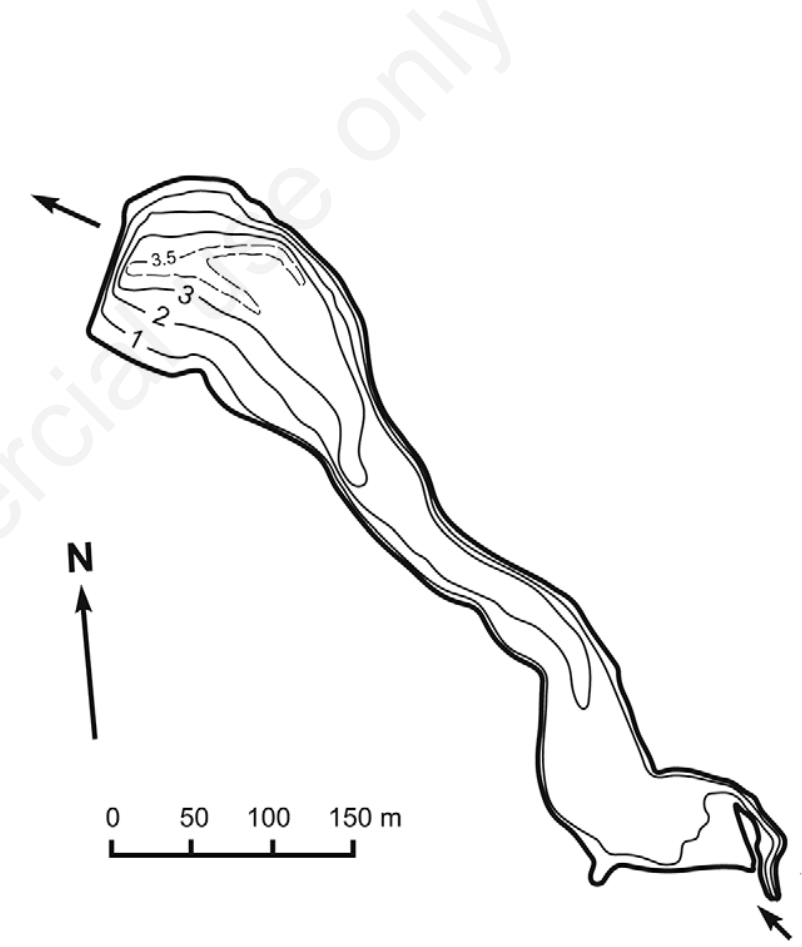

Fig. 1. Bathymetric map of the Jiřická Pond in 2014. Isobath labels are given in meters. Arrows indicate the water flow direction.

Tab. 1. Morphology, hydrology and water chemistry characteristics of the Jiřická Pond (mean values of 3-weekly sampling during 2012-2014).

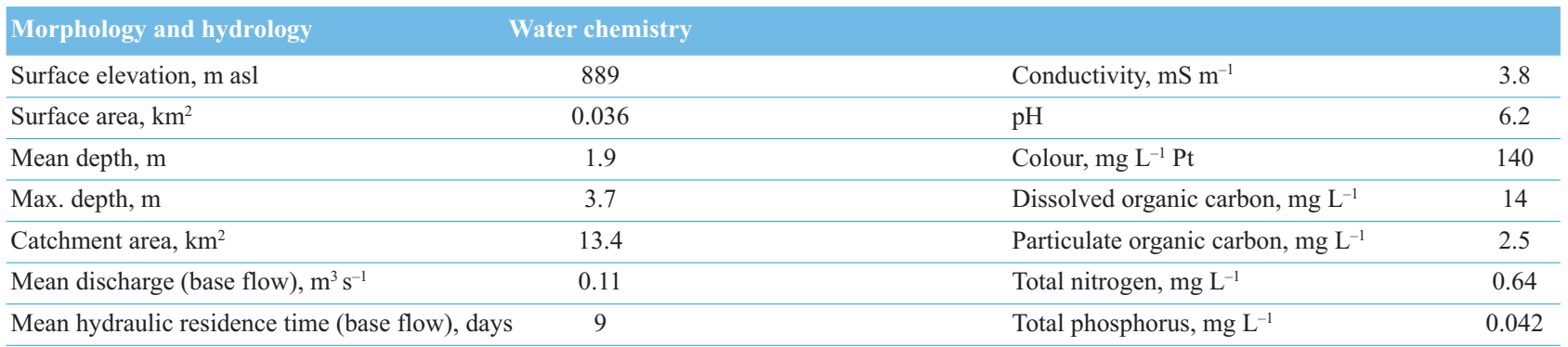


system (NIS-Elements 3.0, LIM, Prague, Czech Republic).

Zooplankton species were sampled at the same site as the limnological variables. Zooplankton was collected during three months from April 5 to July 4, 2014. Due to zooplankton has slow growth, sampling where collected every 4-7 days. Crustaceans were sampled by vertical hauls using an Apstein plankton net (net mesh $200 \mu \mathrm{m}$ ). The hauls were taken from a depth of approx. $4 \mathrm{~m}$ to the surface, which mainly represents the depth of $1 \mathrm{~m}$ above the bottom. This plankton net was selected since its effectiveness has been tested previously (Straskraba and Hrbacek, 1966). The rotifers were also sampled from the uppermost $4 \mathrm{~m}$ of the water column using a plastic tube of the appropriate length. A total of $55 \mathrm{~L}$ of the sampled water were subsequently filtered by a $35 \mu \mathrm{m}$ net. The zooplankton samples were preserved in $4 \%$ formaldehyde and the abundances of each zooplankton species found were determined microscopically (McCauley, 1984). The number of parthenogenetic eggs of some of the most persistent species was also recorded and fecundity was estimated as the number of eggs per fertile female and per total number of individuals. The instantaneous birth rate $\left(b\right.$, days $\left.^{-1}\right)$ of these species was calculated using Edmonson-Paloheimo's method (EP) (Paloheimo, 1974):

$$
b=\frac{\ln (E+1)}{D},
$$

where $E$ is the egg ratio (i.e., number of eggs produced per female) and $D$ is embryo development time which depends on temperature. $D$ values for each group, i.e., cladocerans and rotifers were calculated using functions published by Bottrell (1976) and taking into account the water temperature. Intrinsic growth rate $\left(r\right.$ days $\left.^{-1}\right)$ was obtained as:

$$
r=\frac{\ln \left(\frac{N_{t 2}}{N_{t 1}}\right)}{t},
$$

where $N_{t 1}$ and $N_{t 2}$ are the number of individuals in one specific sampling and in the next one, respectively. $t$ is the time interval between those two samplings.

Finally, death rates $\left(d\right.$, days $\left.^{-1}\right)$ were also estimated as:

$$
d=b-r
$$

Moreover, zooplankton diversity was expressed by the Shannon-Weaver (Shannon and Weaver, 1963) and Simpson indices (Simpson, 1949) from data of each sampling for rotifers and crustaceans, separately. Additionally, the instantaneous birth and intrinsic growth rates were determined for the most persistent cladoceran and rotifer species. The effect of species and samplings on birth and death rates were tested separately by one-way ANOVA, or by one-way robust ANOVA when variances were not homogeneous. Moreover, post-hoc pairwise comparison using Tukey's or Games-Howell (heterogeneous variances) tests were used in those cases in which statistical difference was detected.
Additionally, time series analyses were performed. Species were classified into the following taxonomic groups: Large Daphnia, small cladoceran, calanoid copepod, cyclopoid copepod, and rotifer. Firstly, autocorrelation coefficients were calculated for the time series data of each taxon to explore if the abundance value of each taxonomic group depends on its own previous abundance values. Secondly, to examine the relationships among environmental variables and zooplankton temporal dynamics and identify the time-lag relations, the following cross-correlations between parameters were performed using Pearson's correlation coefficient: i) between dilution rate and the environmental variables, i.e., temperature, chlorophyll a, DOC, POC, bacteria biovolume, HNF biovolume, and ciliate biovolume; ii) between dilution rate and cladoceran and rotifer groups, i.e., large Daphnia, small cladocerans, and rotifers; iii) between each environmental variable and each cladoceran and rotifer group; iv) and between time series of cladoceran and rotifer groups. Before autocorrelation and cross-correlation analyses, Jarque-Bera test (Jarque and Bera, 1987) was used to evaluate if each time series data had a normal distribution. We applied a log-transformation to the time series data to reach a normal distribution when it was needed. Due to calanoid and cyclopoid copepod data distribution were not normal, even after log-transformation, data were not used in the analyses. Then, before cross-correlation analyses, augmented Dickey-Fuller test (Brocklebank and Dickey, 2003), and Mann-Kendall test (Mann, 1945) were used to test if each time series data was stationary and had a trend, respectively. Additionally, each time series (i.e., abiotic and zooplankton data) was differencing, i.e., the differences between consecutive observations were computed, to make time series stationary (in some cases second-order differencing was required) and, hence, meet the assumptions of cross-correlation test. The significance of the CCF at different lags was obtained for each pair time series data comparison.

All statistical analyses were performed using R statistical software v. 3.2.2 (R Core Team, 2015). For robust analyses, the 'robust' and 'userfriendlyscience' packages were used (Wang et al., 2010; Peters et al., 2015). For time series analyses, the 'tseries' (Trapletti and Hornik, 2016), 'kendall'(McLeod, 2011), and 'forecast' (Hyndman, 2016) packages were used.

\section{RESULTS}

\section{Limnological variables}

During the three months in which the Jiřická Pond was studied, the dilution rate under the basic flow regime was approximately $12 \%$ per day (8-28\%) (Fig. 2A). However, two high inflow episodes with dilution rates above $100 \%$ per day occurred in the middle and at the end of May. Dur- 
ing the first high flow event, the amount of water flowing through the pond was approximately five times its volume within three days. The second high flow event happened 11 days later and the amount of water flowing through was seven times the pond volume within three days.

The autocorrelation calculation (Tab. 2) yielded significant correlations in all environmental time series data except dilution. Not significant autocorrelations were found for time series data regarding zooplankton taxa. Cross-correlation analysis showed that dilution rate has effect on the other environmental variables except on ciliate biovolume (Tab. 3). In general, abiotic variables correlated with short lags of dilution rate. Although surface temperature tended

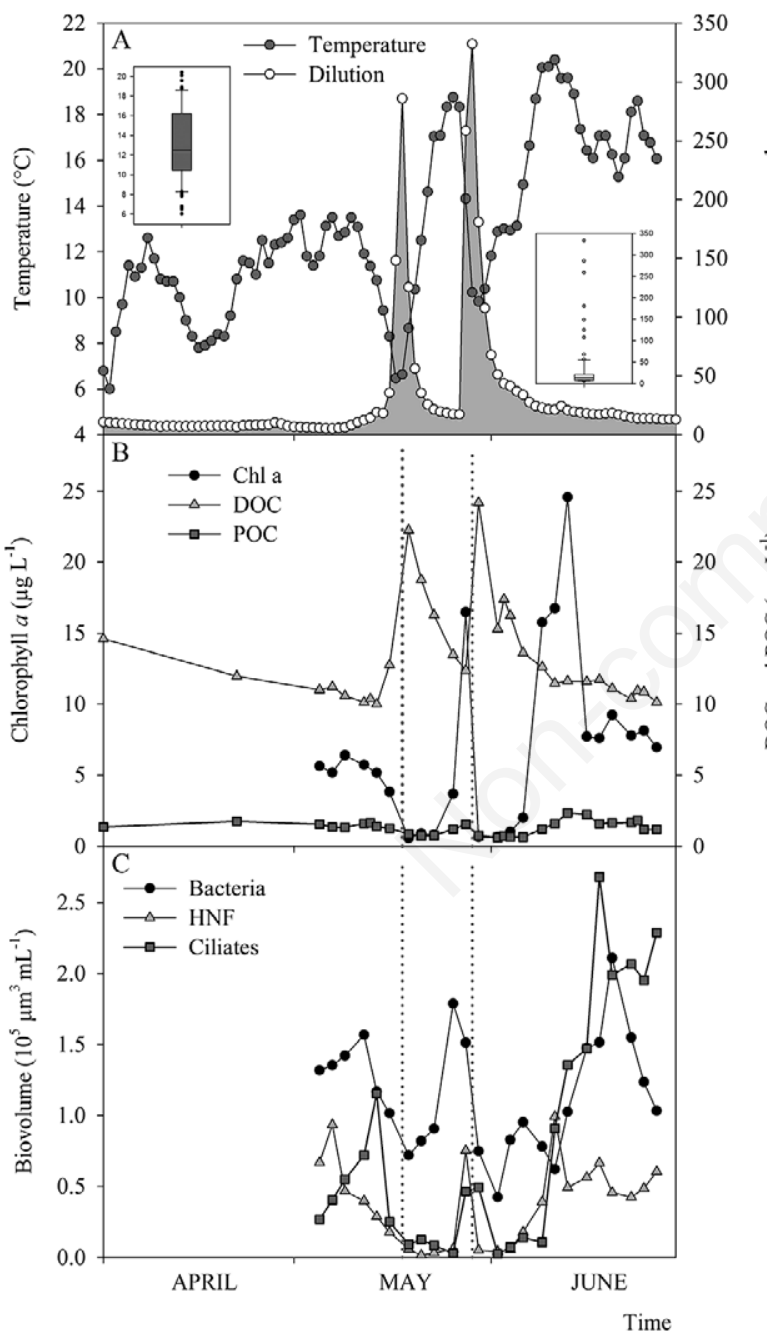

Fig. 2. Environmental parameters measured during the studied period: (A) Dilution rates $(\%)$ and temperature $\left({ }^{\circ} \mathrm{C}\right),(\mathrm{B})$ Chlorophyll $a\left(\mu \mathrm{g} \mathrm{L}^{-1}\right)$, dissolved organic carbon (DOC, $\mathrm{mg} \mathrm{L}^{-1}$ ) and particulate organic carbon (POC, $\mathrm{mg} \mathrm{L}^{-1}$ ), and (C) Total bacterial, heterotrophic nanoflagellates and ciliates cell biovolume. Vertical dotted lines show peaks of the high flow events. to increase (Fig. 2A), after each high flood event, with a statistically significant time lag of 2 days with the dilution rate, the temperature markedly decreased by 7 and $9^{\circ} \mathrm{C}$, respectively. The median value of $\mathrm{Chl} a$ during the study period was $6 \mu \mathrm{g} \mathrm{L}^{-1}$ (Fig. 2B). After both high floods, Chl $a$ also dropped down to almost zero values being statistically significant correlated with the dilution rate at lag of 2 days. DOC and POC showed, in general, constant values during the studied period (median= 11.9 and $1.3 \mathrm{mg} \mathrm{L}^{-1}$, respectively), but two DOC peaks took place. DOC was correlated with time lag of 2, 8 and 10 days with the dilution rate but the highest correlation was with time lag of 2 days. Regarding microbial plankton (Fig. 2C), bacteria, HNF, and ciliate biovolumes showed a similar pattern, with a remarkable drop when floods happened. In fact, bacteria and HNF were correlated with time lag of 2 and 6 days, respectively, with the dilution rate. The microplankton was able to recover its biovolume in the short period between these two floods (see Fig. 2C for details).

\section{Zooplankton species}

During the study, 43 rotifer species (bdelloid rotifers were not identified at species level, so all of them were

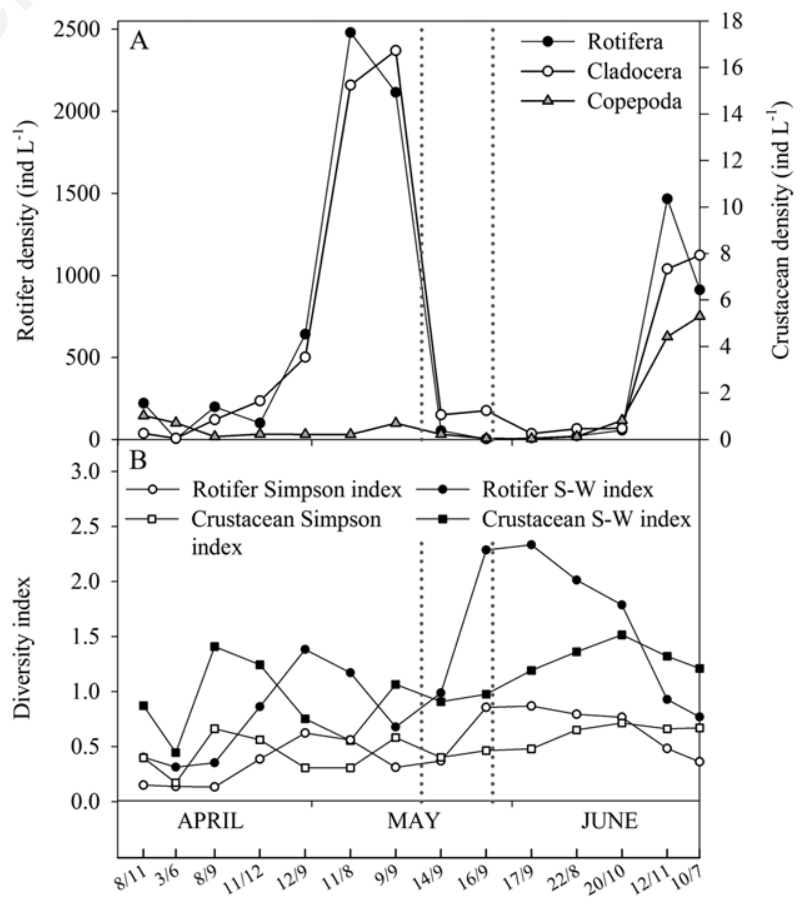

Fig. 3. (A) Rotifer, cladoceran and copepod abundances and (B) Shannon-Weaver and Simpson diversity indexes for rotifer and crustacean species, separately represented. The figures under the lower horizontal axis indicate the species number found in each sampling (rotifers/crustaceans). Vertical dotted lines show the peaks of the high flow events. 
classified in the same group) and 15 crustacean species were identified (all ostracods were also classified in the same group because they were not identified at species level) (Tab. 4). Rotifers represent $72.4 \%$ of the species found in Jiřická Pond and their abundances were up to two orders of magnitude higher than that of crustaceans. Zooplankton monitoring started at the beginning of the spring growing season, just 10 days after the ice melted. In April, the abundance of all zooplankton groups (i.e., Rotifera, Cladocera and Copepoda) was low (Fig. 3). However, at the beginning of May, zooplankton abundance increased and reached a spring peak, defined as the timing when maximum density of zooplankton was reached in spring. The most remarkable increase was shown by rotifers, whose abundance was 2500 rotifers $\mathrm{L}^{-1}$, while the peaks of cladocerans and copepods, were lower (16 and 1 ind $\mathrm{L}^{-1}$, respectively). The ratio between the rotifer and crustacean abundances was 147:1. After the first abundance peak, crustacean abundances as well as rotifer populations notably decreased until near zero values. Although rotifer abundance began declining before high floods, the decrease of the abundance was particularly notable when the great floods happened. At the middle of June there was a second peak of zooplankton

Tab. 2. Significant autocorrelation values ( $(\mathrm{ACF})$ ) for each time series data of environmental variables. Data in the table show only the autocorrelation coefficients statistically significant at the 5\% level.

\begin{tabular}{|c|c|c|}
\hline Environmental variable & Significant autocorrelation values (r(ACF)) & Time (days) derived from the autocorrelation lags \\
\hline Temperature & 0.737 & 2 \\
\hline Chlorophyll $a$ & 0.435 & 2 \\
\hline DOC & 0.438 & 2 \\
\hline POC & 0.692 & 2 \\
\hline Bacteria & 0.568 & 2 \\
\hline HNF & 0.45 & 2 \\
\hline \multirow[t]{3}{*}{ Ciliates } & 0.786 & 2 \\
\hline & 0.643 & 4 \\
\hline & 0.472 & 6 \\
\hline
\end{tabular}

DOC, dissolved organic carbon; POC, particulate organic carbon.

Tab. 3. Cross-correlations between dilution rate and (A) abiotic variables, and (B) taxonomic zooplankton groups; and (C) temperature and taxonomic groups. Data in the table show only the time lag (days) statistically significant at the 5\% level.

\begin{tabular}{|c|c|c|}
\hline \multirow[b]{2}{*}{ (A) Abiotic factors } & \multicolumn{2}{|c|}{ Dilution rate } \\
\hline & Value & lag \\
\hline \multirow[t]{2}{*}{ Temperature } & -0.440 & -2 \\
\hline & 0.492 & 2 \\
\hline \multirow[t]{2}{*}{ Chlorophyll a } & 0.442 & -8 \\
\hline & 0.546 & 2 \\
\hline \multirow[t]{3}{*}{$\mathrm{DOC}$} & 0.428 & 10 \\
\hline & -0.502 & 8 \\
\hline & -0.640 & 2 \\
\hline POC & 0.482 & -14 \\
\hline \multirow[t]{2}{*}{ Bacteria } & -0.587 & -4 \\
\hline & 0.475 & 2 \\
\hline $\mathrm{HNF}$ & -0.454 & -6 \\
\hline (B) Taxonomic groups & Value & lag \\
\hline Large Daphnia & 0.528 & 7 \\
\hline \multirow[t]{2}{*}{ Small cladocerans } & -0.699 & 0 \\
\hline & \multicolumn{2}{|c|}{ Temperature } \\
\hline (C) Taxonomic groups & Value & lag \\
\hline Large Daphnia & 0.644 & 14 \\
\hline Small cladocerans & 0.576 & 0 \\
\hline
\end{tabular}

DOC, dissolved organic carbon; $P O C$, particulate organic carbon. 
abundance, i.e., a summer peak. Rotifer and cladoceran abundances were lower than in the first peak (1500 rotifers $\mathrm{L}^{-1}$ and 8 cladocerans $\mathrm{L}^{-1}$ ) while copepod abundance was higher $\left(5.5\right.$ copepods $\left.\mathrm{L}^{-1}\right)$. Again, the ratio between rotifer and crustacean was high, 111:1. Taking into account the abundance of all the species in the pond, crustacean and rotifer diversity indexes (both ShannonWeaver and Simpson indexes) were high at the middle and at the end of April, respectively (Fig. 3). After 2-3 weeks, the diversity values were the lowest detected for both groups, caused by the massive presence of the cladoceran Eubosmina longispina $\left(13\right.$ ind $\mathrm{L}^{-1}$ while the average of all crustaceans was 1.4 ind $\mathrm{L}^{-1}$ ) and the rotifer Polyarthra dolichoptera (1736 ind $\mathrm{L}^{-1}$ while the average of all rotifer species was 49 ind $\mathrm{L}^{-1}$ ). After the two high flow events, species diversity increased. This was especially notable for rotifers whose diversity index reached its maximum value just four days after the floods, being 3.4 and 2.78-fold (respectively for Shannon-Weaver and Simpson indices) higher than before the floods. Crustacean also reached its highest diversity indexed in the second part of the study but 18 days after the flood events.

Statistical analysis found that time series data of cladoceran and rotifer groups were not autocorrelated. Concerning cross-correlation coefficients, analyses found a statistically significant correlation between dilution rate and both large and small cladocerans but not with rotifer time series (Tab. 3). Temperature also correlated with large Daphnia and small cladocera abundance (Tab. 3). However, no correlation was detected between Chl $a$,

Tab. 4. Species detected in Jiřická Pond during the period studied and the percentage of samples in which species occurred.

\begin{tabular}{|c|c|c|c|}
\hline Species & $\%$ & Species & $\%$ \\
\hline \multicolumn{4}{|l|}{ Cladocera } \\
\hline Ceriodaphnia sp. & 100 & Leydigia leydigii (Schoedler, 1863) & 73 \\
\hline${ }^{*}$ Holopedium gibberum Zaddach, 1855 & 100 & Daphnia longispina (O.F. Müller, 1776) & 53 \\
\hline${ }^{*}$ Eubosmina longispina (Leydig, 1860) & 93 & Acroperus harpae (Baird, 1834) & 27 \\
\hline Diaphanosoma brachyurum (Liévin, 1848) & 80 & Alona sp. & 20 \\
\hline Chydorus sphaericus (O.F. Müller, 1776) & 73 & & \\
\hline \multicolumn{4}{|l|}{ Copepoda } \\
\hline${ }^{*}$ Mesocyclops leuckarti (Claus, 1857) & 100 & Acanthodiaptomus sp. & 20 \\
\hline${ }^{*}$ Eudiaptomus gracilis (Sars G.O., 1863) & 93 & Eucyclops serrulatus (Fischer, 1851) & 7 \\
\hline Thermocyclops crassus (Fischer, 1853) & 47 & & \\
\hline \multicolumn{4}{|l|}{ Ostracoda } \\
\hline Ostracod sp. & 20 & & \\
\hline \multicolumn{4}{|l|}{ Rotifera } \\
\hline${ }^{*}$ Polyarthra dolichoptera Idelson, 1925 & 100 & Polyarthra euryptera Wierzejski, 1891 & 13 \\
\hline Synchaeta pectinata Ehrenberg, 1832 & 87 & Lecane luna (Müller, 1776) & 13 \\
\hline${ }^{*}$ Synchaeta oblonga Ehrenberg, 1832 & 80 & Lecane obtusa (Murray, 1913) & 13 \\
\hline Keratella cochlearis (Gosse, 1851) & 80 & Colurella uncinata (Müller, 1773) & 13 \\
\hline Ascomorpha ecaudis Perty, 1850 & 73 & Filinia longiseta (Ehrenberg, 1834) & 13 \\
\hline Asplanchna priodonta Gosse, 1850 & 73 & Trichotria tetractis (Ehrenberg, 1830) & 13 \\
\hline${ }^{*}$ Conochilus unicornis Rousselet, 1892 & 60 & Trichocerca roseola (Stenroos, 1898) & 7 \\
\hline Microcodon clavus Ehrenberg, 1830 & 60 & Trichocerca rouseleti (Voigt, 1902) & 7 \\
\hline Keratella valga (Ehrenberg, 1834) & 53 & Trichocerca sp. & 7 \\
\hline Lecane lunaris (Ehrenberg, 1832) & 53 & Pompholyx sulcata Hudson, 1885 & 7 \\
\hline Trichocerca porcellus (Gosse, 1851) & 47 & Brachionus budapestinensis Daday, 1885 & 7 \\
\hline Ploesoma hudsoni (Imhof, 1891) & 40 & Lecane closterocerca (Schmarda, 1859) & 7 \\
\hline Bdelloidea sp. & 40 & Lepadella patella (Müller, 1773) & 7 \\
\hline Lepadella acuminata (Ehrenberg, 1834) & 33 & Colurella colurus (Ehrenberg, 1830) & 7 \\
\hline Cephalodella cf. Gibba (Ehrenberg, 1830) & 33 & Encentrum sp. & 7 \\
\hline Lecane flexilis (Gosse, 1886) & 27 & Testudinella clypeata (Müller, 1786) & 7 \\
\hline Gastropus hyptopus (Ehrenberg, 1838) & 27 & Testudinella patina & 7 \\
\hline Testudinella incisa (Ternetz, 1892) & 27 & Proalides subtilis Rodewald, 1940 & 7 \\
\hline
\end{tabular}

*The species detected, in at least one sample, with abundances which represented more than $50 \%$ of the total abundance in a given group. 
DOC, POC, Bacteria, HNF, or ciliate and cladoceran and rotifer groups (data not shown). Regarding biotic relationships, cross-correlation analysis evidenced few statistically significant coefficients between zooplankton groups. Analyses only found a statistically significant correlation between rotifers and small cladocerans (cross-correlation coefficient $=0.894$ at lag 0 ).

The most persistent species in the pond were the ro- tifers P.dolichoptera, Synchaeta pectinata, S. oblonga and Keratella cochlearis; the cladocerans Ceriodaphnia sp., Holopedium gibberum, E. longispina and Diaphanosoma brachyurum; and the copepods Eudiaptomus gracilis and Mesocyclops leuckarti (occurrence in $>80 \%$ of the samplings). The dynamics and instantaneous birth rates of several of the most persistent rotifer and cladoceran species are shown in Fig. 4. Since the parthenogenetic

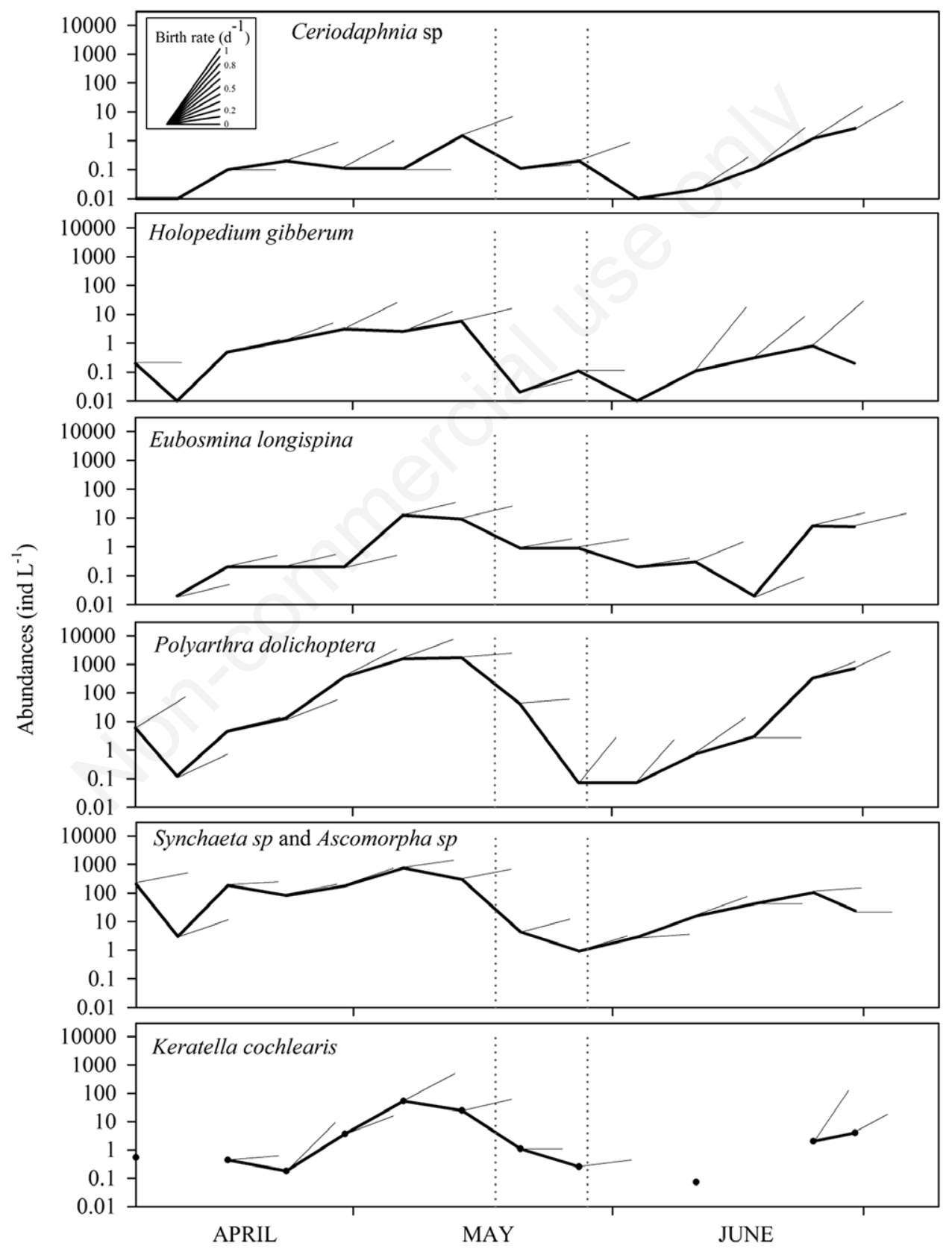

Fig. 4. The abundance dynamics and instantaneous birth rates per day of the most persistent cladoceran and rotifer species during the period studied. Vertical dotted lines show the peaks of the high flow events. 
eggs of Synchaeta sp. and Ascomorpha sp. are extremely similar, it was not possible to differentiate between these species so both are represented together.

There were no significant differences among species in the death rates $(\mathrm{P}=0.292)$ but there were in birth rates $(\mathrm{P}<0.001)$. However, when pairwise comparisons of the species birth rates were tested, the post-hoc analysis did not find statistical differences (all $\mathrm{P}>0.084$ ). The lowest value of birth rate was measured for the zooplankton collected two days after the high flow event (average all species $=0.09$ days $\left.^{-1}\right)$. However, no statistically significant differences between samples were found when species birth rates were compared $(\mathrm{P}=0.108)$. In contrast, ANOVA results showed that the sampling date had an effect on death rates $(\mathrm{P}<0.001)$. Post-hoc pairwise comparisons revealed that this significant effect was caused mainly by rates corresponding to the second sampling when death rates were very different compared to the other samplings (average $=-0.4$ days $^{-1}$, statistically different from five samplings, all $\mathrm{P}<0.023$ ). A negative death rate may mean that the growth rate was higher than the birth rate, which is possible, for example, if population density also increases as a consequence of the recruitment by hatchlings from diapausing eggs. This situation corresponds in Fig. 4 to those cases in which the birth rate line is below the growth rate line. Five of the six species explored had negative rates in the second sampling which correspond to early April when the zooplankton growing season starts (there is no data about the birth rate of $K$. cochlearis from this sampling). Moreover, after the second high flood event, the cladoceran $E$. longispina and the rotifers $P$. dolichoptera and Synchaeta/Ascomorpha sp. also had negative mortalities in the middle of June, when these species showed a notable increase in their abundances.

\section{DISCUSSION}

Our study gives evidence that rotifers completely dominate the zooplankton community in Jiřická Pond. This finding agrees with previous studies focused on zooplankton communities in highly fluctuating environments (Geraldes and Boavida, 2007). Strong flood events during the spring season are the main drivers that notably favour the dominance of rotifers in the water column. On the one hand, as expected, due to rotifer species have great colonization ability (Allan, 1976), they are able to reach higher abundances faster than crustacean after the adversity situation caused by floods, although both taxonomic groups show the signals from the recovery at the same time. On the other hand, although repeated disturbance caused by high flood events declined the species abundances, it seems to influence positively on rotifers since species number and diversity are increased.

According to empirical evidence, zooplankton com- munities (i.e., their composition, abundance, and dynamics) are affected by physical and chemical factors and the relative importance of these effects depends on the strength of fluctuations in these factors (Wetzel, 2001). In most lakes and reservoirs, it has been demonstrated that low fluctuations in abiotic factors contribute a greater stability to the system (Geraldes and Boavida, 2005). According to the flushing rates recorded in Jiřická during Spring 2014, this mountain pond may be considered to be an unpredictable, fluctuating system since two strong episodes of strong water flow were recorded during a short period of time, i.e., three months. As expected, these episodes caused drastic changes in physical conditions and in the zooplankton community. Temperature and chlorophyll $a$ showed a notable decrease as a consequence of extensive water replacement by the flood. The flood event seems to act as the principal factor causing the zooplankton abundance to decrease to almost undetectable values. Our results have clearly indicated that cladoceran abundance was affected mainly by temperature and dilution rate, but we did not find statistic support to the effect of dilution rate and temperature on the rotifer dynamics. The abiotic factors such as temperature and chlorophyll $a$ approached the pre-flood levels within a few days, and reached their maximum values 7 days later. However, more time was required for the recovery of the zooplankton species. The delay in the zooplankton recovery could be a consequence of the decreasing food resource (i.e., low chlorophyll $a$, bacteria, HNF, and ciliates); however, no significant correlations among both chlorophyll $a$ and potential food resources, measured as the microplankton biovolumes (i.e., bacteria, HNF, and ciliates), and the densities of zooplankton species were found, in contrast to what would be expected. Mac Donagh et al., (2009) suggested that the inflow/outflow may affect the relative importance of other variables in the structure of a zooplankton community. Accordingly, a plausible explanation for the absence of correlations in our study may be that the effect of the high flood events in the middle of spring is so strong that the other effects are being masked.

There has been evidence that when a water body is characterized by pronounced water fluctuations, those zooplankton organisms with specific, adaptive advantages will dominate the community (Schmid-Araya and Zuñiga, 1992; Bledzki and Ellison, 2000; Geraldes and Boavida, 2007). Several features, including life-history traits and feeding mechanisms, have been pointed out. Taking that into account, a plankton community is expected to be dominated by $r$-strategists when the system is characterized by strong fluctuations (Flores and Barone, 1994; Schmid-Araya and Schmid, 1995; Baranyi et al., 2002; Geraldes and Boavida, 2007). Based on several findings, the community in Jiřická Pond agrees with this pattern in several aspects. Firstly, it was found that microplankton 
(i.e., chlorophyll $a$ as an indirect measure of algal biomass, and heterotrophic biovolume) with fast population growth, recovered quickly after being entirely washed out from the pond. Secondly, rotifers became the dominant zooplankton group in terms of species number and abundance, utilizing their ability to rapidly colonize the water column. The crustacean abundance in the pond never exceeded 17 ind $\mathrm{L}^{-1}$, which is extremely low compared to the abundance of rotifers. Although rotifers generally are present at higher abundances than crustacean species in reservoirs and lakes, the ratio found in our system between their abundances is extremely high (average ratio of rotifer:crustacean abundance in Jiřická Pond=126:1) and notably differ from the ratio recorded in other aquatic systems with higher retention times. For example, the average ratio in Slapy Reservoir (Czech Republic) with 57 days of average time retention is 10:1 (Devetter, 2011); in Řimov Reservoir (Czech Republic) with 90 days of average time retention is 5:1 (Seda and Devetter, 2000); in Saidenbach Reservoir (Germany) with 220 days of average time retention is 4:1 (Hülsmann et al., 2012; personal communication ); or in Lake Śniardwy (Poland) with 260 days of average time retention is 2.5:1 (Ejsmont-Karabin and Kufel, personal communication). This difference in the abundances is likely to be related to their longer generation times (Allan, 1976; Herzig, 1984) which involve a slow growth in the water column. And thirdly, the most dominant species of Cladocera was not Daphnia as it is known to occur in stable water bodies (Geraldes and Boavida, 2007) but Ceriodaphnia sp., H. gibberum and E. longispina, which are species typically found in higher abundances in more disturbed aquatic systems (Baranyi et al., 2002; Geraldes and Boavida, 2007). Compared to Daphnia, these smaller cladocerans have shorter generation times and hence have more ability to sustain washout losses induced by flood events. Moreover, these species seem to feed upon smaller particles and are more tolerant of large amounts of dissolved organic matter (DOC) in the water than Daphnia individuals (Rellstab et al., 2007). Due to the effect of DOC is less important for rotifers (Kirk and Gilbert, 1990; Kirk, 1991; Pollard et al., 1998), we expected DOC to be an important driver on the zooplankton community structure of the Jiřická Pond, since DOC concentrations increased during flood periods. However, not statistical support was found.

In addition to high growth rates, the recruitment of hatchlings from diapausing eggs facilitates a rapid re-colonization of the water column, even by species within the community experiencing several consecutive demographic catastrophes related to severe changes in habitat character (Kalisz, 1991). Although we did not explore the diapausing egg bank, we found several cues that may, indirectly, indicate that diapause is playing an important role in the community structure of Jirrická Pond. On the one hand, after the ice melted and the two high food events, the population growth rates of explored species were higher than birth rates which could take place when the population increases through new hatchlings from diapausing eggs. However, this finding should be carefully interpreted since birth rate could be underestimated because the rate was calculated based on temperature and number of eggs, but other factors such as food quality and quantity have effect on zooplankton birth rates (King, 1967; Orcutt and Porter, 1984; Urabe, 1991). On the other hand, other cue that brings to suggest the diapausing egg bank role is the fact that after the great disturbance, the rotifer diversity and richness also increased reaching its maximum value and new species appeared in the water column which likely arose from the hatching of diapausing eggs after egg being realising and being exposed to hatching cues by the inflow effect (Vaníčková et al., 2011). Nevertheless, this study was not performed to explore diapause role and direct evidences were not found. At this point, the diapause role is only a hypothesis which would be worth to be explored in further studies.

Biotic interactions, like abiotic factors, influence also in the zooplankton community dynamics and composition. Two of these factors are the common exploitative competition between cladocerans and rotifers and the fish predation on zooplankton (Gilbert, 1988; Gliwicz and Pijanowska, 1989; Nielsen et al., 2000; Hansson et al., 2007). In our study, the lack of a negative correlation between cladoceran and rotifer abundances suggests the absence of a strong competitive ability of the cladocerans over rotifers in the Jiřická Pond. This finding is consistent with the fact that rotifers are commonly outcompeted by larger-bodied cladocerans (Brooks and Dodson, 1965; Gilbert, 1988; MacIsaac and Gilbert, 1989). Nevertheless, as mentioned above, the most representative cladocerans in this system are small species. These small-bodied species, in turn, could have a negative effect on rotifers due to an intense competition for resources only if they are present at sufficiently high density (Hurtado-Bocanegra et al., 2002) which, again, was not the case in our system. Regarding the potential effect of fish predation, it is known that minnows (Phoxinus phoxinus) are relatively abundant fish species in the Jiřická Pond as they migrate from small streams in the pond watershed into the pond itself. Thus, the low abundances of cladocerans may be explained, at least in part, by fish predation pressure. Crustacean species are more susceptible to zooplanktivorous fish selection than rotifers because fish generally prefer larger species (Brooks and Dodson, 1965; O'Brien et al., 1976; Zaret, 1980), which is evident from the clear negative correlation between fish and large cladoceran abundances in natural communities (Hrbacek, 1962; Dawidowicz and Pijanowska, 1984; Bergquist et al., 1985; Enríquez García et al., 2009). Additionally, rotifers could be 
negatively affected by invertebrate predation by copepods but we could not test statistically this effect.

Our findings thus highlight the importance of the repeated disturbed caused by flood events on the zooplankton community of this small mountain pond. We conclude that the zooplankton community in Jiřická Pond may be classified as a 'rotifer kingdom'. The enhanced precipitation rates in the small watershed of this mountain pond result in rapid oscillations of inflow rates with extreme, short-lived flood events. These high inflow episodes were the most decisive factors driving the dynamics and composition of the zooplankton community compared to other abiotic and biotic factors. Moreover, the rotifer dominance in this pond is additionally favoured because its population seems to be unconstrained by competition with cladocerans and likely by the pressure of copepod predation. Both a high amount of suspended particles and the presence of zooplanktivorous fish probably act as contributing factors negatively affecting large cladocerans. In turn, high rotifer abundance likely favours the production of a large number of diapausing eggs being relevant to the persistence of rotifers in the water column after disturbances.

\section{CONCLUSIONS}

Determining the factors and mechanisms that explain the community structure is one of the major issues in ecology. Life-history traits, biotic interactions and environmental fluctuations have been demonstrated to play an important role. In aquatic systems, the flushing rate sometimes operates as an important factor because of inflow water may washout part or even the total zooplankton population. However, the flow rate and its effects on the water retention time in reservoirs and lakes have received less attention in the ecological studies of zooplankton communities. We found that repeated high flood events, caused by the high precipitations, enhance the dominance of rotifer species and its diversity in the zooplankton community of a small dammed mountain pond during spring season. Two effects are likely to be occurring synchronously to account for this situation: i) re-colonization from resting egg bank, and ii) decreasing competition effects between taxa when populations are diluted. Accordingly, we document that flood disturbance can enhance the species diversity and maintain the dominance of species with short generation time.

\section{ACKNOWLEDGMENTS}

The linguistic revision of the paper was done by Mary Morris. We thank Robert Pacák and Iva Dostalková for fruitful discussions on improvement of statistical analyses of our data set. The comments and advice of two anonymous referees improved the paper greatly and are appreciated.

\section{FUNDING}

This work was supported by the Czech Science Foundation projects 15-24309S and 13-00243S.

\section{REFERENCES}

Alekseev V, Lampert W, 2001. Maternal control of resting-egg production in Daphnia. Nature 414:899-901.

Alekseev V, Ravera O, de Stasio B, 2007. Introduction to diapause, p. 3-10. In: V. Alekseev, B. de Stasio and J. Gilbert (eds.), Diapause in aquatic invertebrates theory and human use. Springer, Dordrecht.

Allan J, 1976. Life history patterns in zooplankton. Am. Nat. 110:165-180.

Angeler DG, Alvarez-Cobelas M, Rojo C, Sánchez-Carrillo S, 2000. The significance of water inputs to plankton biomass and trophic relationships in a semi-arid freshwater wetland (central Spain). J. Plankton Res. 22:2075-2093.

Arnott SE, Vanni MJ, 1993. Zooplankton assemblages in fishless bog lakes: influence of biotic and abiotic factors. Ecology. 74:2361-2380.

Ban S, 1994. Effect of temperature and food concentration on post-embryonic development, egg production and adult body size of calanoid copepod Eurytemora affinis. J. Plankton Res. 16:721-735.

Baranyi C, Hein T, Holarek C, Keckeis S, Schiemer F, 2002. Zooplankton biomass and community structure in a Danube River floodplain system: effects of hydrology. Freshwater Biol. 47:473-482.

Bergquist A, Carpenter SR, Latino JC, 1985. Shifts in phytoplankton size structure and community composition during grazing by contrasting zooplankton assemblages. Limnol. Oceanog. 30:1037-1045.

Bledzki L, Ellison A, 2000. Effects of water retention time on zooplankton of shallow rheolimnic reservoirs. Verhand. Int. Verein. Theor. Angew. Limnol. 27:2865-2869.

Bottrell H, 1976. A review of some problems in zooplankton production studies. Nor. J. Zool. 24:419-456.

Brendonck L, De Meester L, 2003. Egg banks in freshwater zooplankton: evolutionary and ecological archives in the sediment. Hydrobiologia 491:65-84.

Brocklebank J, Dickey D, 2003. SAS for forecasting time series. SAS institute.

Brooks J, Dodson S, 1965. Predation, body size, and composition of plankton. Science 50:28-35.

Bundy M, Vanderploeg H, 2002. Detection and capture of inert particles by calanoid copepods: the role of the feeding current. J. Plankton Res. 24:215-223.

Cáceres C, 1997. Dormancy in invertebrates. Invertebr. Biol. 116:371-383.

Cáceres C, 1998. Interspecific variation in the abundance, production, and emergence of Daphnia diapausing eggs. Ecology 79:1699-1710. 
Checkly DMJ, 1982. Selective feeding by Atlantic herring ( Clupea harengus) larvae on zooplankton in natural assemblages. Mar. Ecol. Prog. Ser. 9:245-253.

Chou WR, Fang LS, Wang WH, Tew KS, 2012. Environmental influence on coastal phytoplankton and zooplankton diversity: a multivariate statistical model analysis. Environ. Monit. Assess. 184:5679-5688.

Dawidowicz P, Pijanowska J, 1984. Population dynamics in cladoceran zooplankton in the presence and absence of fishes. J. Plankton Res. 6:953-959.

De Meester L, Gómez A, Simon J, 2004. Evolutionary and ecological genetics of cyclical parthenogens, p. 122-134. In: A. Moya and E. Font (eds.), Evolution from molecules to ecosystems. Oxford University Press.

Devetter M, Seda J, 2003. Rotifer fecundity in relation to components of microbial food web in a eutrophic reservoir. Hydrobiologia 504:167-175.

Devetter M, 2011. Seasonal development of planktonic rotifers in Slapy Reservoir (Czech Republic). Biologia (Bratisl) 66:662-668.

Dickman M, 1969. Some effects of lake renewal on phytoplankton productivity and species composition. Limnol. Oceanogr. 14:660-666.

Enríquez García C, Nandini S, Sarma SSS, 2009. Seasonal dynamics of zooplankton in Lake Huetzalin, Xochimilco (Mexico City, Mexico). Limnologica 39:283-291.

Flores LN, Barone R, 1994. Relationship between trophic state and plankton community structure in 21 Sicilian dam reservoirs. Hydrobiologia 275-276:197-205.

García-Roger EM, Carmona MJ, Serra M, 2006. Patterns in rotifer diapausing egg banks: Density and viability. J. Exp. Mar. Bio. Ecol. 336:198-210.

George D, Hewitt D, 1990. The relative effects of enrichment and climate change on the long-term dynamics of Daphnia in Esthwaite Water, Cumbria. Freshwater Biol. 23:55-70.

Geraldes AM, Boavida MJ, 2005. Seasonal water level fluctuations: Implications for reservoir limnology and management. Lakes Reserv. Res. Manag. 10:59-69.

Geraldes AM, Boavida MJ, 2007. Zooplankton assemblages in two reservoirs: one subjected to accentuated water level fluctuations, the other with more stable water levels. Aquat. Ecol. 41:273-284.

Giebelhausen B, Lampert W, 2001. Temperature reaction norms of Daphnia magna: the effect of food concentration. Freshwater Biol.46:281-289.

Gilbert J, 1988. Suppression of rotifer populations by Daphnia: a review of the evidence, the mechanisms, and the effects on zooplankton community structure. Limnol. Oceanogr. 33:1286-1303.

Gilbert J, Schröder T, 2004. Rotifers from diapausing, fertilized eggs: unique features and emergence. Limnol. Oceanogr. 49:1341-1354

Gillooly JF, 2000. Effect of body size and temperature on generation time in zooplankton. J. Plankton Res. 22:241-251.

Gliwicz ZM, Pijanowska J, 1989. The role of predation in zooplankton succession, p. 253-296. In: U. Sommer (ed.), Plankton ecology. Springer.

Hairston NG, 1996. Zooplankton egg banks as biotic reservoirs in changing environments. Limnol. Oceanogr. 41:10871092 .
Hairston NG, Van Brunt RA, Kearns CM, Engstrom DR, 1995. Age and survivorship of diapausing eggs in a sediment egg bank. Ecology 76:1706-1711.

Hansson, LA, Nicolle A, Brodersen J, Romare P, Nilsson PA, Brönmark C, Skov C, 2007. Consequences of fish predation, migration, and juvenile ontogeny on zooplankton spring dynamics. Limnol. Oceanogr. 52:696-706.

Herzig A, 1984. Fundamental requirements for zooplankton production studies. Limnol. Institute of Austrian Academy of Science, 83 pp.

Hirche HJ, Meyer U, Niehoff B, 1997. Egg production of Calanus finmarchicus: effect of temperature, food and season. Mar. Biol. 127:609-620.

Hrbacek J, 1962. Species composition and the amount of zooplankton in relation to the fish stock. Naklad. Cesk. Akad. Ved. 72:1-16.

Hurtado-Bocanegra MD, Nandini S, Sarma SSS, 2002. Combined effects of food level and inoculation density on competition between Brachionus patulus (Rotifera) and the cladocerans Ceriodaphnia dubia and Moina macrocopa. Hydrobiologia 468:13-22.

Hůelsmann S, Wagner A, Pitsch M, Horn W, Paul R, Rother A, Zeis B, 2012. Effects of winter conditions on Daphnia dynamics and genetic diversity in a dimictic temperate reservoir. Freshwater Biol. 57:1458-1470.

Hyndman R, 2016. R package forecast: forecasting functions for time series and linear models. Available from: https:// github.com/robjhyndman/forecast

Jarque C, Bera A. 1987. A test for normality of observations and regression residuals. Int. Stat. Rev. 55:163-172.

Jenkins DG, Buikema AL, 1998. Do similar communities develop in similar sites? A test with zooplankton structure and function. Ecol. Monogr. 68:421-443.

Kalisz S, 1991. Experimental determination of seed bank age structure in the winter annual collinsia verna. Ecology $72: 575$

Kerfoot WC, 1977. Implications of copepod predation. Limnol. Oceanogr. 22:316-325.

Kilham S, Kreeger D, Goulden C, Lynn S, 1997. Effects of algal food quality on fecundity and population growth rates of Daphnia. Freshwater Biol. 38:639-647.

King CE, 1967. Food, age, and the dynamics of a laboratory population of rotifers. Ecology 48:111-128.

Kirk KL 1991. Inorganic particles alter competition in grazing plankton: the role of selective feeding. Ecology 72:915-923.

Kirk KL, Gilbert J, 1990. Suspended clay and the population dynamics of planktonic rotifers and cladocerans. Ecology 71:1741-1755.

Lorenzen C, 1967. Determination of chlorophyll and pheopigments:spectrophotometric equations. Limnol. Oceanogr. 12:343-346.

Mac Donagh ME, Casco MA, Claps MC, 2009. Plankton relationships under small water level fluctuations in a subtropical reservoir. Aquat. Ecol. 43:371-381.

MacIsaac HJ, Gilbert J, 1989. Competition between rotifers and cladocerans of different body sizes. Oecologia 81:295-301.

Mann HB, 1945. Nonparametric tests against trend. Econometrica 13:245-259.

Marcus NH, Lutz R, Burnett W, Cable P, 1994. Age, viability, and vertical distribution of zooplankton resting eggs from 
an anoxic basin: Evidence of an egg bank. Limnol. Oceanogr. 39:154-158.

McCauley E, 1984. The estimation of the abundance and biomass of zooplankton in samples. In: A.J. Downing and F.H. Rigler (eds.), A manual on methods for the assessment of secondary productivity in fresh waters. Blackwell.

McLeod A, 2011. R-package kendall: Kendall rank correlation and Mann-Kendall trend test.

Moore PA, Fields DM, Yen J, 1999. Physical constraints of chemoreception in foraging copepods. Limnol. Oceanogr. 44:166-177.

Niehoff B, 2004. The effect of food limitation on gonad development and egg production of the planktonic copepod Calanus finmarchicus. J. Exp. Mar. Bio. Ecol. 307:237-259.

Nielsen DL, Hillman TJ, Smith FJ, Shiel RJ, 2000. The influence of a planktivorous fish on zooplankton assemblages in experimental billabongs. Hydrobiologia 434:1-9.

O'Brien WJ, Slade NA, Vinyard GL, 1976. Apparent size as the determinant of prey selection by bluegill sunfish (Lepomis macrochirus). Ecology 57:1304-1310.

Orcutt JD, Porter KG, 1984. The synergistic effects of temperature and food concentration of life history parameters of Daphnia. Oecologia 63:300-306.

Paloheimo JE, 1974. Calculation of instantaneous birth rate. Limnol. Oceanogr. 19:692-694.

Peters G, Peters M, XLConnect S, 2015. Package "userfriendlyscience".

Pollard AI, González MJ, Vanni MJ, Headworth JL, 1998. Effects of turbidity and biotic factors on the rotifer community in an Ohio reservoir. Hydrobiologia 387:215-223.

Pourriot R, Snell T, 1983. Resting eggs in rotifers. Hydrobiologia 104:213-224.

Quintana Pou X, Boix Masafret D, Badosa i Salvador A, Brucet Balmaña S, Compte Ciurana J, Gascón Garcia S, López i Flores R, Sala Genoher J, Moreno i Amich R, 2006. Community structure in mediterranean shallow lentic ecosystems: size-based vs. taxon-based approaches. Limnetica 25:303-320.

R Core Team, 2015. R: A language and environment for statistical computing. R Foundation for Statistical Computing. R Foundation for Statistical Computing, Vienna, Austria.

Ramdani M, Elkhiati N, Flower RJ, Thompson JR, Chouba L, Kraiem MM, Ayache F, Ahmed MH, 2009. Environmental influences on the qualitative and quantitative composition of phytoplankton and zooplankton in North African coastal lagoons. Hydrobiologia 622:113-131.

Rellstab C, Maurer V, Zeh M, Bürgi HR, Spaak P, 2007. Temporary collapse of the Daphnia population in turbid and ultra-oligotrophic Lake Brienz. Aquat. Sci. 69:257-270.

Schmid-Araya J, Schmid P, 1995. Preliminary results on diet of stream invertebrate species: the meiofaunal assemblages. Jahresbericht Biol. Stn. Lunz. 15:23-31.

Schmid-Araya J, Zuñiga L, 1992. Zooplankton community structure in two Chilean reservoirs. Arch. Hydrobiol. 123:305-335.

Seda J, Devetter M, 2000. Zooplankton community structure along a trophic gradient in a canyon-shaped dam reservoir. J. Plankton Res. 22:1829-1840.

Shannon C, Weaver W, 1963. The mathematical theory of communication. University of Illinois Press.

Simek K, Hornak K, Jezbera J, 2008. Spatio-temporal patterns of bacterioplankton production and community composition related to phytoplankton composition and protistan bacterivory in a dam reservoir. Aquat. Microb. Ecol. 51:249-262.

Simek K, Nedoma J, Znachor P, Kasalický V, Jezbera J, Hornák $\mathrm{K}$, Seda J, 2014. A finely tuned symphony of factors modulates the microbial food web of a freshwater reservoir in spring. Limnol. Oceanogr. 59:1477-1492.

Simpson EH, 1949. Measurement of diversity. Nature 163:688.

Slusarczyk M, 1995. Predator-induced diapause in Daphnia. Ecology 76:1008-1013.

Straskraba M, Hrbacek J, 1966. Net-plankton cycle in Slapy Reservoir 1958-1960. In: J. Hrbacek (ed.), Hydrobiological studies 1. Academia, Prague: 115 pp.

Threlkeld ST, 1982. Water renewal effects on reservoir zooplankton communities. Can. Water Resour. J. 7:151-167.

Trapletti A, Hornik K, 2016. tseries: Time Series Analysis and Computational Finance. http://cran.r-project.org/package= tseries.

Urabe J, 1991. Effect of food concentration on growth, reproduction and survivorship of Bosmina longirostris (Cladocera). Freshwater Biol. 25: 1-8.

Vaníčková I, Sed'a J, Macháček J, Petrusek A, 2011. Effects of extreme floods on the Daphnia ephippial egg bank in a long narrow reservoir. J. Limnol. 70:369-377.

Wang J, Zamar R, Marazzi A, Yohai V, Salibian-Barrera M, Maronna R, Zivot E, Rocke D, Martin D, Maechler M, Konis K, 2010. Robust: Insightful Robust Library.

Wetzel R, 1990. Reservoir ecosystems: conclusions and speculations. In: K.W. Thornton (ed.), Reservoir limnology: ecological perspectives. J. Wiley \& Sons, Chichester.

Wetzel R, 2001. Limnology: lake and river ecosystems. Gulf Professional Publishing.

Zaret T, 1980. Predation and freshwater communities. Yale University Press, New Haven. 